Article

\title{
Valuation of the Vocationality of Cultural Heritage: The Vesuvian Villas
}

\author{
Fabiana Forte ${ }^{1}$, Vincenzo Del Giudice ${ }^{2}$, Pierfrancesco De Paola ${ }^{2, *(D)}$ and Federica Troisi ${ }^{1}$ \\ 1 Department of Architecture and Industrial Design, University of Campania "Luigi Vanvitelli", \\ Via San Lorenzo ad Septimum, 81031 Aversa, Italy; fabiana.forte@unicampania.it (F.F.); \\ federicatroisi@outlook.com (F.T.) \\ 2 Department of Industrial Engineering, University of Naples "Federico II", Piazzale Vincenzo Tecchio 80, \\ 80125 Naples, Italy; vincenzo.delgiudice@unina.it \\ * Correspondence: pierfrancesco.depaola@unina.it; Tel.: +39-081-768-2933
}

Received: 20 December 2019; Accepted: 24 January 2020; Published: 28 January 2020

check for updates

\begin{abstract}
The Vesuvian Villas are a system of architectural assets that, due to important artistic, historical and typological characteristics, have relevance that is not only local. However, due to ineffective management policies and insufficient financial resources, the system of the Vesuvian Villas is subject to abandonment or to invasive transformations for speculative purposes. The management policies for these real estate goods would require a profound theoretical and operational review that, together with the overcoming of the binding instrument as the only guarantee of protection, pursues conservation through synergies founded on appropriate uses of the Vesuvian Villas. This innovative path is difficult to implement due to the substantial rigidity of the architectural structures and the transformations aimed at renewing the forms of use, but mostly for the lack of available financial resources. Starting from the analysis of the relationships between conservation and transformation of the historical architectural asset, the paper proposes a multicriteria analysis model for the evaluation of the "vocational" nature of the "Villa Vesuviana" property, aimed to its conservative reuse. This suitability was assessed starting from a set of indicators explaining the actual state of the building (typological, morphological, structural and artistic characteristics) and its location. The indicators have been evaluated through qualitative judgments made using the hierarchical analysis technique. Particular attention was paid to the evaluation of synergies deriving from complementary uses.
\end{abstract}

Keywords: vocationality; cultural heritage; Analytic Hierarchy Process (AHP); Vesuvian Villas; valuation

\section{Introduction}

In accordance with the report "Cultural Heritage Counts for Europe", in the past few decades we have witnessed the main conceptual and policy developments that have recognized the multiple and valuable benefits that cultural heritage brings to society as a whole [1], making the conservation of cultural heritage a national priority for many countries. At a European Union level, starting from the Faro Convention (2005), there has been a growing awareness of the importance of cultural heritage, recognized as "a strategic resource for a sustainable Europe" (Council of the European Union, 2014 [2]) and "a shared resource and a common good", as in the document "Towards an integrated approach to cultural heritage for Europe" (European Commission, 2014 [3]). In this document it is also highlighted that the economic value of heritage has recently come into research focus, but only partial estimates of its importance are available.

It is clear that the issue of the evaluation of impacts connected with the valorization of Cultural Heritage has become relevant also in the policy agendas [4]. Most recently, during 2018, the EU has 
celebrated the importance of Cultural Heritage in Europe with a list of events hosted throughout Europe in order to remind its citizens of the linkage that binds each other and to enhance a common sense of belonging to the European Union (Heritage Hube, 2018). The Davos Declaration 2018, "Towards a high-quality Baukultur for Europe", recognized cultural heritage as "a crucial component of high-quality Baukultur. The way we use, maintain and protect our cultural heritage today will be crucial for the future development of a high-quality built environment."

With specific regard to Italy, the State, through the Ministry for Heritage, Cultural Activities and Tourism-MiBACT-is not only responsible for the strategic task involved in the protection of an extremely rich cultural heritage, but has direct responsibility for the management of a huge number of national heritage institutions. Protection and Management is regulated by the Italian Code of the Cultural and Landscape Heritage (Legislative Decree n. 42/2004). Public expenditures, allocated by several levels of government, have traditionally been the primary source in supporting Cultural Heritage; however, they have been progressively reduced, with Italy being, among the EU states, one of those who spends less on culture, despite its extraordinary heritage [5].

As in other European countries, the involvement of private subjects (both profit and non-profit) in the preservation of Cultural Heritage has become a relevant issue. As several studies and reports in the field of Cultural Economics have highlighted for a long time, the traditional approach that considered this heritage as "immutable" has been overcome by an approach that recognizes its vitality or productivity [6], as well as its preservation, and is understood as a "productive" activity carried out for "social use" [7]. It is in this sense that the notion of valorization should be interpreted.

In Italy, the theme of valorization has been particularly debated since there is a "culture of conservation" that prevails and it enforces a very ancient legislative tradition (it starts from the period that precedes the unification of Italy, passing from the 1939 legislation), which must be "proudly" defended, but there was no a "culture of valorization". In other words, the country has invested very little in its cultural heritage. As set out in the Italian Code of the Cultural and Landscape Heritage, valorization (or enhancement) consists of the exercise of the functions and regulation of the activities aimed at promoting knowledge of the cultural heritage as well as ensuring the best conditions for the use and public enjoyment of the heritage. A private subject may concur, co-operate or participate in such activities. Then, in a purely economic interpretation, it is possible to consider valorization as a way for the "entrepreneurial" management of the cultural heritage, capable of producing revenues for its preservation or care [8]. It is important to underline that this interpretation does not aim to increase the market value attributable to cultural asset, but rather to attract resources for financing its conservation and accessibility [9], providing it with the "social plus value" [10].

This obviously represents the economic gain and the social benefit yielded through the conservation, which - as it obtains a greater value - may be also understood as valorization. According to the Council of Europe, "private management is currently the most interesting area for involving the private sector in protection of the cultural heritage. It can take many forms and extend from management of State property to management of privately owned heritage" [11]. In this perspective, among the different forms of management of cultural property undertaken by private initiatives introduced by the Italian Code and aimed at the valorization, are Sponsorship and Additional Services; both have been analyzed, highlighting some critical aspects [12,13].

The most recent government reform on the overall system of cultural goods and activities, launched by the MiBACT with an "Art Bonus" Decree (Legislative Decreen. 83/2014 and successive modifications) encourages cash donations for the care of public cultural property, trying to align Italy to others European countries, but not to the USA where the fiscal incentives for the historic preservation are, traditionally, so much more consistent [14]. Together with this innovative form of incentives, the Legislative Decree n. 83/2014 introduces the Strategic Plan for "Major Cultural Patrimony Projects", with the aim of identifying goods or sites of exceptional cultural interest and of national relevance for which it is necessary and urgent to realize organic interventions of conservation, requalification, valorization and cultural promotion for the tourism sector, assigning several resources. Further, in 2012, 
the Italian Revenue Agency, with Invitalia and ANCI and other institutional subjects, the "Valore Paese-Dimore" program for the valorization of historical-artistic public patrimony was promoted.

The program aims to develop and put at work publicly owned properties for tourist accommodation that are of particular historic and artistic merit and located in sites of significance in terms of the environment and landscape. Among several properties that fall under the portfolio of immovable cultural properties of the "Valore Paese-Dimore" program, there is the bourbon Villa Favorita in Ercolano, in the metropolitan city of Naples and in the territorial development system "Miglio d'Oro-Area Torrese Stabiese", the object of analysis in the next paragraphs.

If all these recent institutional initiatives regard the cultural property owned by the Italian State, the question of financing the valorization of cultural property owned by private subjects is far more delicate and complex. Private cultural properties have a normative treatment that is different from the other private goods, since they are of public relevance. In fact, private subjects, owners of historic proprieties (historical villas, castles, palace, etc.) are obliged, by law (Legislative Decree n. 42/2004), to conserve and maintain their properties. The ministry may contribute to the expenses, both with capital grants and interest subsidies.

The owners who have received contributions are obliged to make the property accessible to the public, according to the modalities fixed, case by case, by special conventions. For each kind of intervention, there is a need for authorization from the competent authority and for the sale of the property the state has the power to purchase it by pre-emption. Against conservation obligations, for which the private subject must maintain the property at its own expense and under its responsibility (also penal), traditionally the state reserves to the private owner a less burdensome tax regime, a sort of "compensation". Nevertheless, in the last years, private cultural properties are facing a number of important challenges to survive.

Specifically, the property tax of listed buildings, which in the past was calculated on the basis of a symbolic value, the so called "figurative rent" from 2012 with the "Salva Italia" Decree, has been increased dramatically, making the taxable income the effective rent. This increase of the tax burden on the historical properties, conjointly with the forthcoming cadastral reform and the many bureaucratic bonds, are making the maintenance and valorization of the cultural property owned by private entities even more difficult. Thus, the ADSI ("Associazione Dimore Storiche Italiane" or Italian Association of Historical Houses) proposal presented to the government in 2015 is particularly efficacious.

It consists of the reduction by $30 \%$ of the property tax (the IUC- "Imposta Comunale Unica" or Municipal Single Tax-introduced in 2014 by Italian Stability Law) for owners of historic properties under the condition that they have to invest not only into the restoration but also in the valorization of properties, improving the services for their enjoyment, setting up a network with other realties in the territory and promotional activities.

This means that all "additional services" according to the analysis could generate a VAT revenue capable of compensating for the reduction of the property tax, but also, in the best case, further revenues for the state to re-invest in activities of valorization, communication and education for the enjoyment of the cultural heritage, in the form of multiplier effects [15].

However in Italy, where the private cultural properties are consistent (only the Italian Historic Houses, monitored by ADSI, are estimated to be around 45-50 thousand and diffused on all the national territory), the listed buildings are not all valuable historical mansions, localized in the central areas of the cities. Many listed buildings are located in secondary villages, in rural areas or in small municipalities in each part of the country. If they are of historic and cultural interest, they are degraded and of scarce economic and income value, as is the system of Vesuvian Villas, in the metropolitan area of Naples (Campania region). The opportunity to deepen some aspects regarding the care of private cultural property [15] derives from the participation in the Campus Project "Urban Ecotourism for the sustainable use of cultural heritage in Campania" (in implementation of the Operational Program ERDF Campania 2007/2013), managed by the Regional Center of Competence Benecon (Cultural Heritage, Ecology, Economics), of which one of the partners is the University of Campania "Luigi 
Vanvitelli. The project in fact involves the development system "Miglio d'Oro-Area Torrese Stabiese", with 12 municipalities that constitute a "landscape-cultural mosaic" of considerable interest, where there are concentrated not only goods of "outstanding universal value" (the UNESCO sites of the archeological areas of Pompei, Ercolano and Torre Annunziata), but also immovable goods of notable cultural interest, both public and private, such as the historic houses (villas and mansions) with gardens annexed, some designed and realized by famous architects (Vanvitelli, Sanfelice, Fuga, Vaccaro etc.) and an expression of one of the most florid Neapolitan periods (the Bourbon age).

Some of these historic houses are part of Authority for Vesuvian Villas (now a Foundation) instituted with state Law no. 578/1971 that provides to conserve, restore and valorize them. In 1976, with the Ministerial Decree of constrain, the work of the authority started for the preservation of the 122 monumental buildings in the territory of the municipalities of Naples, San Giorgio a Cremano, Portici, Ercolano and Torre del Greco. Only a restricted number of these historical buildings have been restored and valorized, or are under transformation, as Villa Favorita in Ercolano thanks to the "Valore Paese-Dimore" program. Many others are in a serious condition, with physical and functional obsolescence or have been abandoned.

The case showed in this article was developed by the authors on the base of the application made by D'Alpaos et al., concerning the possibility of the reconversion of the historic Venetian villas as museums [16].

\section{Multicriteria Decision Making}

The Analytic Hierarchy Process (AHP), developed by Saaty at the end of the 1970s, makes it possible to prioritize a series of alternative decisions or to relate criteria characterized by qualitative and quantitative evaluations (not directly comparable) combining multidimensional measure scales in a single scale of priorities [17].

The method is based on paired comparisons between the criteria, giving them a score of relative importance and ends with the assignment of a percentage weight.

The scores to be used for each comparison are arbitrary (random) and correspond to the number of quality levels to be considered during the pairwise comparisons.

The AHP uses an evaluation scale ranging from 1 to 9, where each ordinal number corresponds to the following values:

- 1. Equal importance.

- 3. Moderate importance.

- 5. Strong importance.

- 7. Very strong importance.

- 9. Absolutely important.

- $\quad 2,4,6$ or 8 . Intermediate values.

The same is for the inverse comparisons.

The evaluation process is divided into phases:

- Structure the problem in the hierarchy model.

- Evaluation of comparative judgment and compilation of the analysis matrix; it consists of measuring the relative importance of the elements with respect to the overall goal.

- Construction of an evaluation matrix and a summary of the priorities.

The hierarchical organization of the AHP method allows a detailed decomposition of the problem in more levels.

The goal is set at the upper level of the structure; at the second level there are the objectives that specify the contents and meanings of the goal, factors, criteria or attributes that contribute to the result. Each of these can be subdivided into more specific elements. The actions to evaluate are located at the lowest level of the hierarchy. 
The subdivision of the problem in successive phases permits to define a series of sub-problems with reduced dimensions and complexity.

Each problem is explained by the compilation of a matrix of comparison in pairs that identify the level of convenience and importance of the same criteria.

The matrix is made up of as many rows as there are actions and columns corresponding to the significant attributes for the solution of the problem.

The comparisons are formulated by a verbal judgment, which is associated with a corresponding numerical value. From all these comparisons it is possible to obtain a result. The "best" is the one characterized by the highest level of convenience.

To detect the consistence of the matrix it is possible to calculate an "index of inconsistency" that shows the divergence of the judgments expressed with respect to an ideal situation where the consistence is perfect.

Saaty defines the "index of inconsistency" as

$$
\text { I.I. }=\frac{\lambda l-n}{n-l}
$$

in which the term $\lambda l$ is the maximum eigenvalue of the matrix A and represents the size of the same matrix. Saaty has shown that the pairwise comparison matrix is perfectly consistent when I. I. is equal to 0 ; the same matrix is perfectly inconsistent when I.I. is equal to 1 . Generally, the acceptability threshold of the index of inconsistency is $10 \%$.

\section{Vesuvian Villas and Model Application}

The study aims to assess the vocationality of the Vesuvian Villas chosen for conservative and economic reuse, using a set of indicators explaining the state of fact of the buildings and their location.

The heterogeneous nature of the criteria considered (technical, economic or social) makes useful the application of an evaluation method of multi-criteria analysis that allows to summarize and analyze at best such complex information.

This method is applied to five villas not managed by the Fondazione Ente Ville Vesuviane, chosen because they have fewer owners.

The villas are all built along Resina Street, the main street of Ercolano that houses most of the eighteenth-century villas. Their distance from the highway exit of Ercolano ranges from $950 \mathrm{~m}$ from Villa Giulio de la Ville to $1150 \mathrm{~m}$ from Villa Lucia. The villas are far from the archaeological site of Herculaneum, $500 \mathrm{~m}$ minimum, $1100 \mathrm{~m}$ maximum.

The five villas studied are

- Villa Giulio de la Ville-38, A. Rossi Street;

- Villa Lucia-390, Resina Street;

- Villa Manes Rossi-321, Resina Street;

- Villa Arena-318, Resina Street;

- Villa Durante-308, Resina Street.

The number of owners of such dwellings varies from one to eleven.

\subsection{The Vesuvian Villas System}

The Vesuvian Villas system is a symbol of richness of the eighteenth century.

They are in the Ercolano municipality, known in the 18th century as the "Golden Mile". It dates back to 1738, when Charles Bourbon decided to move his residence from Naples to Portici (a municipality without interruption of its continuity with Ercolano). Antonio Canevari and Antonio Medrano were the architects who built the Royal Palace of Portici. During all of the eighteenth century the area knew the greatest splendor, with new luxurious buildings and farms. 
After the Second World War, the villas lost their main characteristics due to heavy urbanization. However, these buildings represent a unique concentrate, that can still be recognized today. The Vesuvian Villas are characterized by a central structure and a "double L" plan. Behind them, there are open spaces that define the atriums, the courtyards and the farms. The main façade can be oriented to the street (Golden Mile), to the sea, the Vesuvius or the countryside.

The villas have spectacular parks, with kiosks, fountains, seats and marble busts.

Inside the residences there are sculptures and frescoes with mythological and allegorical scenes.

Unfortunately, in the nineteenth century a series of events changed the configuration of the Vesuvian Villas System a lot.

In 1844 the railway was built; in 1904 and 1925 the Circumvesuviana railway and highway constructions broke down the gardens of the most recent villas.

Now the buildings do not have the function for which they were built; most of them are used as rustic houses, warehouses, restaurants or museums.

Some of these are now managed by the Fondazione Ente Ville Vesuviane, established on 29 July 1971 with Law n. 578/1971. This foundation was created to list, safeguard and enhance the conspicuous artistic and architectural heritage of the 122 Vesuvian Villas located between Naples and the province along the Golden Mile.

\subsection{Villa Giulio de la Ville (1795)}

The Villa was built in 1795 by an unknown architect, and it suffered important alterations over the years (see Figure 1).

The original planimetric configuration arranged the spaces around a court according to a symmetrical succession of buildings with respect to the axis passing through the entrance, the courtyard and the avenue of the original park. On the left side of the main building, there was a small chapel. Thereafter another two-story building was built against the chapel, while others overlooking the garden were demolished.

The condition of the villa can be considered very bad. In the central part of the facade, there are only a few elements of the original structure and the rest of the eighteenth-century decorations.

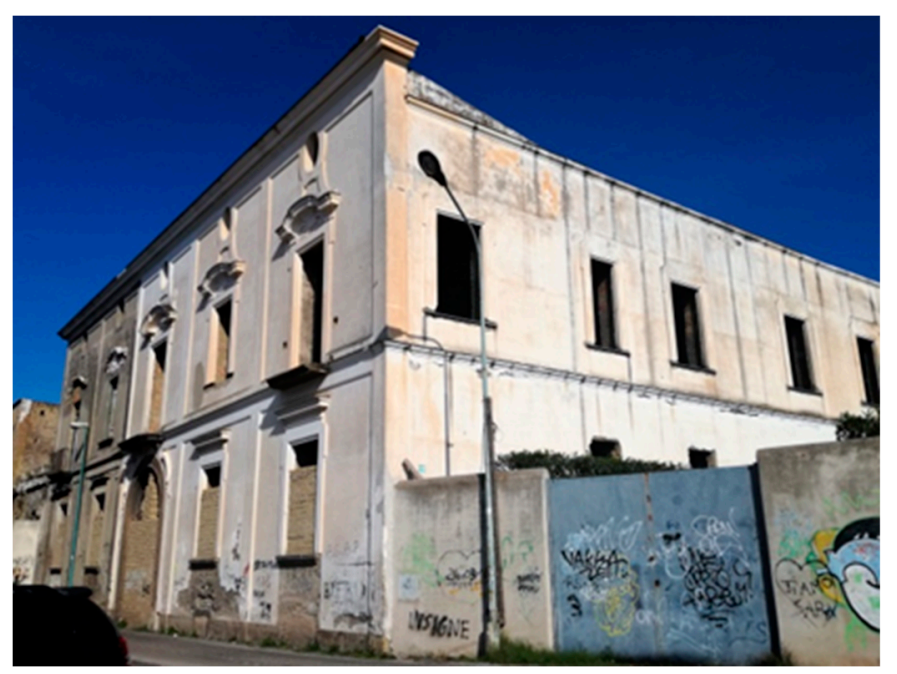

Figure 1. Villa Giulio de la Ville.

\subsection{Villa Lucia (1799)}

Built in 1799, Villa Lucia is in a very bad condition. The architect author of the building and the owners in the years are unknown (see Figure 2).

The " $\mathrm{C}$ " shaped building, on two levels, has a linear facade with openings surmounted by triangular tympanums. 
Inside the courtyard there is a narrow portal with doric pilasters and typical stucco decorations.

At the right edge of the inner facade stands an octagonal tower with a lowered sixth dome, and a pinnacle with volutes in Vesuvius black stone.

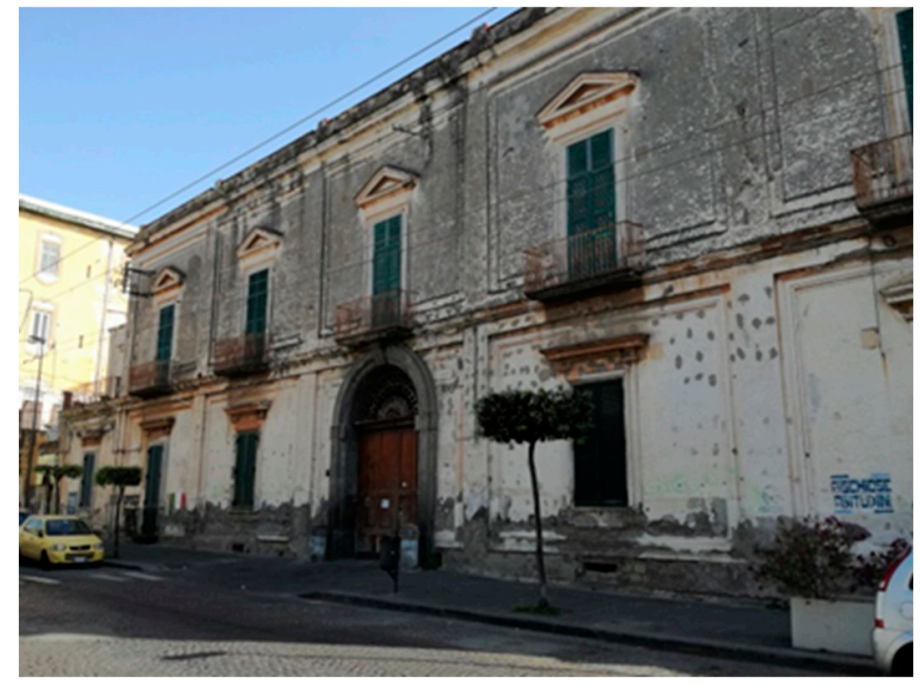

Figure 2. Villa Lucia.

\subsection{Villa Manes Rossi (1760)}

Villa Manes Rossi is a neoclassical building, built around 1760, and composed of a single level beyond the basement (see Figure 3).

The low facade on Corso Ercolano has a piperno base and decorations in the Pompeian style.

Beyond the entrance portal, framed by a pair of windows on each side, a long hallway leads to an open exedra on the well-preserved garden.

In the garden, after the construction of the villa, a two-story building was built.

The state of conservation of the villa can be considered discrete.

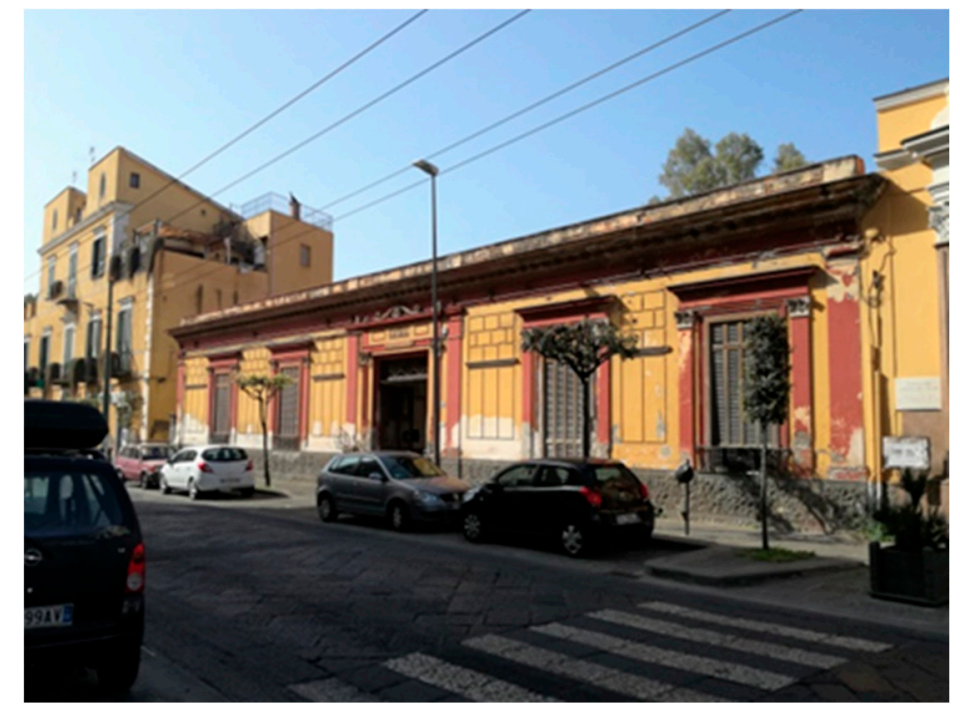

Figure 3. Villa Manes Rossi.

\subsection{Villa Arena (1740-1840)}

This building was built on an eighteenth-century layout of which nothing remains, except the staircase with shaped iron railings inside the courtyard (see Figure 4). 
Villa Arena is on three levels with a listed base.

The first one has balconies framed by triangular and curved tympanums, connected by a single balcony that runs along the entire front and extends towards the rear.

On the main front there are two long neoclassical railings.

Beyond the entrance gate with a piperno portal, there is a deep atrium covered by a coffered vault. Recently elevated structures have replaced the original roof.

The conservation state of the villa is discrete.

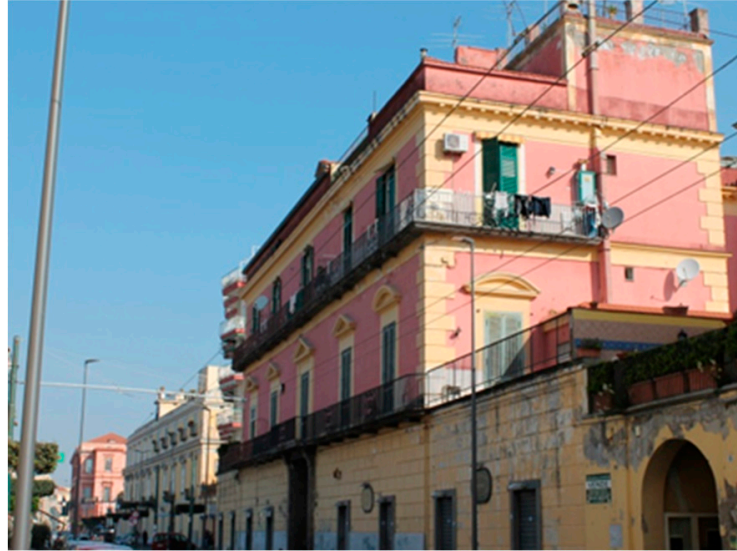

(a)

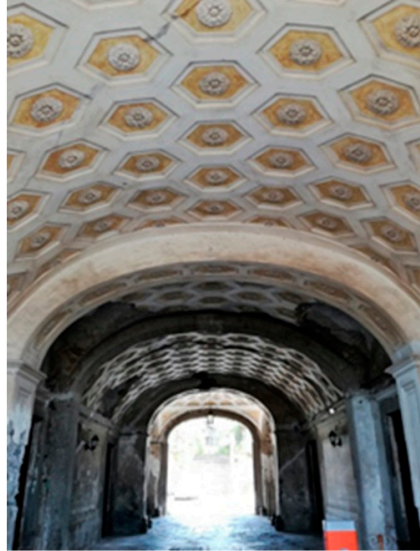

(b)

Figure 4. Villa Arena: main facade (a) and entrance hall (b).

\subsection{Villa Durante and Chapel (1700)}

The ancient structure was built for the Prince of Teora around 1700, and then became property of the Durante family in the 1800s (see Figure 5).

The villa, designed by the Neapolitan architect Ferdinando Sanfelice, is located in a large triangular area.

Its asymmetrical planimetric development is now unaltered, with the exception of the raised floor and the chapel, located in the courtyard.

The small sacred place, containing the statue of St. Gennaro, was also added by the Durante family. The family coat of arms is placed on the front of the building, and reports "Durante Deo domus est", with also a statue of St. Michael the Archangel.

Along the facade there is an alternation of triangular and semicircular tympanums, respectively, containing shells and laurel leaves.

The Villa has two portals with a smooth piperno frame that allow to access to two large atriums.

The garden is opposite, across the royal road. The entrance is characterized by a monumental portal, with a piperno structure and a curved architrave broken in key.

The conservation state of the villa is good. 


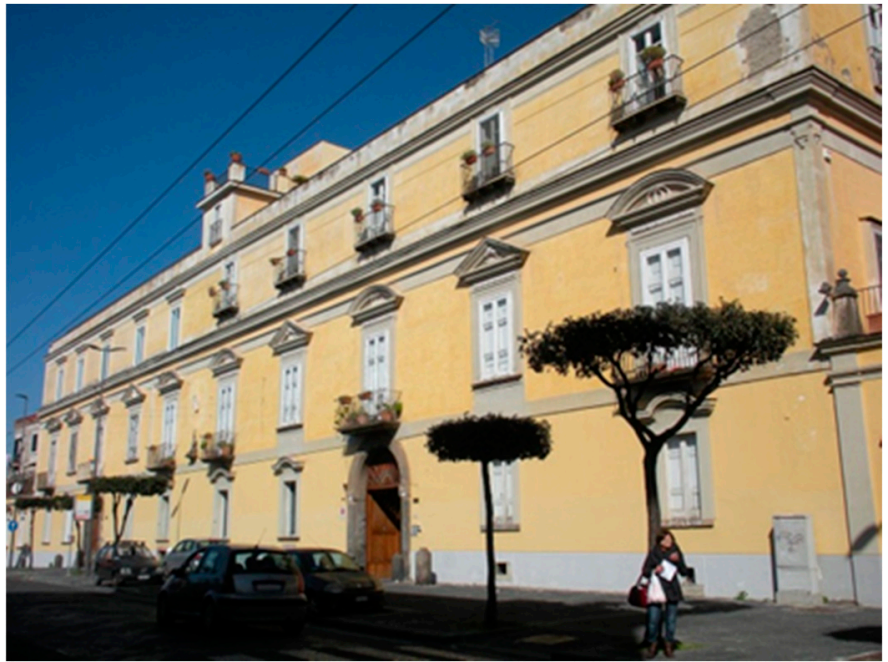

(a)

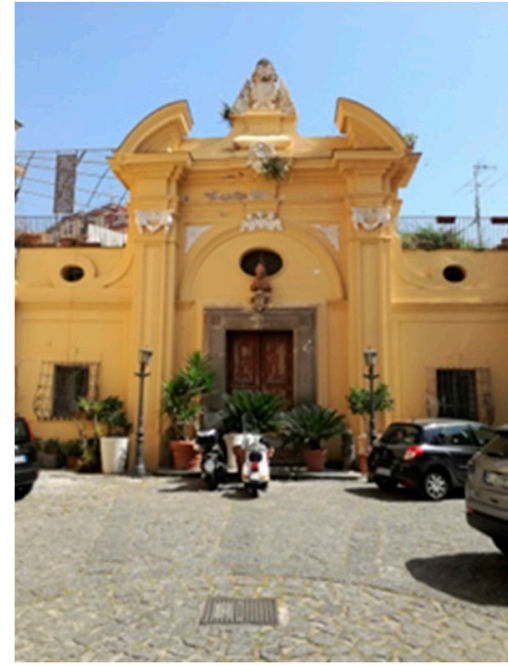

(b)

Figure 5. Villa Durante: main facade (a) and chapel entrance (b).

\subsection{The Evaluation Model (Voc)}

The global evaluation model (Voc) was created in reference to three Vesuvian Villas built in the eighteenth century, as a sub-unit of the larger universe of the Vesuvian Villas system in Ercolano.

These buildings are now managed by the Fondazione Ente Ville Vesuviane, namely, Villa Campolieto, Villa Ruggiero and Villa Favorita.

The model determines an index that represents the Villa's attitudes to a new economical destination. The result is a ranking of vocation of the elements that constitute the model.

The construction of the hierarchic model was done in the following stages:

- Creation of a database of villas with known economic destination (Villa Campolieto, Villa Ruggiero and Villa Favorita).

- Construction of a hierarchical model (Ahp1) for the evaluation of the success of compatible economic reuse and organization of villas according to this parameter $(\mathrm{u})$.

- Construction of hierarchical model (Ahp2) for the evaluation of vocationality (v) and determination of its ranking.

- Analysis of ranking (v) deviations from ranking $(\mathrm{u})$ and calibration of the vocational model.

- Application of the vocational model (Voc) to a real reference.

\subsection{The Assessment of Compatible Economic Use (Model Ahp1)}

The compatible economic use is the possible compromise between the profit of economic use and the conservation status of the historic building.

The villas considered in this part of the work are three villas managed by the Fondazione Ville Vesuviane (see above), because they are already planned for new use (two are museums, and one hosts the municipal library) and represent a significative subset of the Vesuvian Villas system.

The compatible economic use is valued from a group of parameters useful for the analysis of the current uses of buildings, their economic aspect and their general contribution to the conservation of the structure.

All these actions are necessary for the calibration of the reference model, to which will be made the calculations based on the villas chosen as case study.

The parameters used are (see Figure 6)

- Economic activity (ECON);

- Percentage of use of the building (GRU); 
- Building use function (MDU);

- Conservation status (SC).

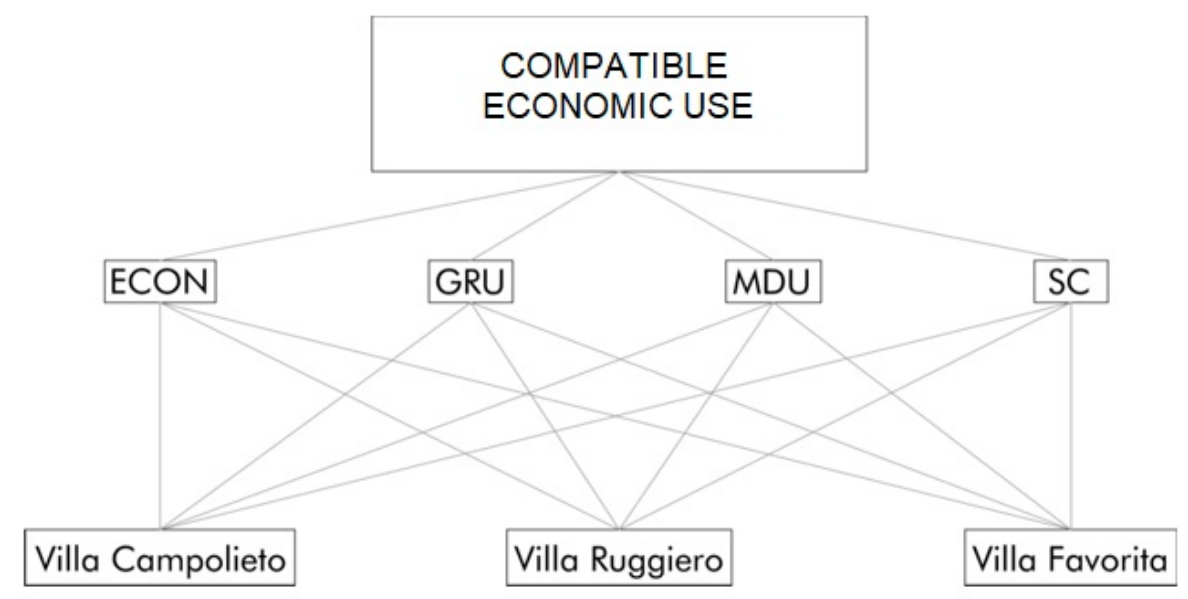

Figure 6. Model of the assessment of compatible economic use (Ahp1).

In particular:

- Villa Campolieto-ECON: museum; GRU: 80\%; MDU: museum, tourist purpose; SC: perfect.

- Villa Ruggiero-ECON: municipal library "G. Buonaiuto"; GRU: 80\%; MDU: public utility; SC: perfect.

- Villa Favorita-ECON: museum partially open to public (called "Casina dei Mosaici”); GRU: $25 \%$; MDU: tourist purpose; SC: mediocre.

\subsection{The Assessment of Vocationality (Model Ahp2)}

The assessment of vocationality of the Vesuvian Villas to an economic reuse is based on the analysis of a set of indicators in the creation of a potential offer for the building use.

The group of factors examined are the (see Figures 7 and 8)

1. Characteristics about the Villa's localization (CLO): Useful for identifying the existence of potential demand for the different economic building uses. These factors are also influenced by the proximity of touristic sites (in this study the archaeological site of Herculaneum is considered). There are

- Importance of the touristic site, measured in yearly number of tourists (PPA);

- Touristic vocation of the site (TPA), indicated with values 1 (touristic site) or 0 (not touristic);

- Distance between the villa and the archaeological site of Herculaneum, measured in meters (DPA);

- Distance between the villa and the nearest highway exit measured in meters (DSA).

2. The intrinsic characteristics of the villa (CIN) is a group of indicators divided into two sub-families.

a. Typological characteristics (CTI): Parameters useful to define the current uses and the possible future ones with particular regard to the spatial composition of the building. There are

- $\quad$ Private garden (PG);

- $\quad$ Nearby parking (PPK); 
- $\quad$ Facade type (TF).

b. Historical and architectural characteristics of the villas (CSA): Parameters useful for an initial list of possible project choices when are planned functional and technological transformations:

- Detection of the architect author of the building (AC);

- Detection of the principal artists of inner decorations (AD);

- Presence of interior frescoes (PAFF);

- Presence of interior decorative stuccoes (PST);

- $\quad$ Presence of internal stone decoration (PDL);

- Presence of precious floors (PPP).

3. Characteristics about the ownership and legal structure (CLE): These factors take information about the ownership structure of the villas and the possible legal limitations. There are

- $\quad$ Type of property (ecclesiastic, private, public, etc.) (TPR);

- Presence of a safeguard limitation derived from National Law (VIN).

In particular, the parameters for the villas managed by the Fondazione Ente Ville Vesuviane, used as reference, are

$\underline{\text { CLO }}$

- Importance of touristic site: 534,328 tourists for the year 2018;

- Economic vocation of the site: Villa Campolieto: touristic; Villa Ruggiero: not touristic; Villa Favorita: touristic.

- Distance between the Villa and the archaeological site of Herculaneum: Villa Campolieto: 695 m; Villa Ruggiero: 752 m; Villa Favorita: 872 m.

- Distance between the Villa and the nearest highway exit: Villa Campolieto: $1115 \mathrm{~m}$; Villa Ruggiero: 975 m; Villa Favorita: 1117 m.

$\underline{\text { CIN }}$

- Villa Campolieto-PG: yes; PPK: free parking $98 \mathrm{~m}$ away; TF: The villa has five levels; the main facade has a piperno plinth and the windows at the first floor have triangular tympanums; the back facade, on the sea, presents an elliptical large portico with round arches, connected to the building by two lowered arches with Tuscan capitals; AC: M. Giuffredo and L. Vanvitelli; AD: J. Cestaro and F. Fischetti; PAFF: yes; PDL: no; PPP: no; PST: yes;

- Villa Ruggiero-PG: yes; PPK: free parking 140 m away; TF: The building has three levels; the facade has stucco ornaments and tympanums around the windows on the first two levels; the portal is made with piperno and white marble, with a round arch; the back facade is typically Rococo; the balconies are framed by volutes in stucco and on the central one there is the niche with the bust of St. Gennaro, symbolically oriented to Vesuvius; AC: unknown; AD: unknown; PAFF: yes; PDL: no; PPP: no; PST: yes;

- Villa Favorita-PG: yes; PPK: free parking $84 \mathrm{~m}$ away; TF: The building, on two levels, has a main facade marked by pairs of pilasters and interrupted by two side portals in piperno and two central windows; on the back facade the protagonist is the large semicircular stone staircase, which the terrace with the park behind is connected; AC: F. Fuga; AD: P. Hackert; PAFF: yes; PPP: no; PDL: yes; PST: yes. 


\section{$\underline{\text { CLE }}$}

- Type of property: All the buildings are managed by Fondazione Ente Ville Vesuviane.

- Presence of a safeguard limitation derived from National Law: all the buildings are limited by the Decree of the Ministry of Cultural and Environmental Heritage of 19.10.1976.

Then, following the previous indicators follow the same parameters for the five villas of the case study:

$\underline{\text { CLO }}$

- Importance of touristic site: 534,328 tourists for the year 2018;

- Economic vocation of the site: touristic;

- Distance between the Villa and the archaeological site of Herculaneum: Villa Giulio de la Ville: 725 m; Villa Lucia: 1254 m; Villa Manes Rossi: 1160 m; Villa Arena: 598 m; Villa Durante: $480 \mathrm{~m}$.

- Distance between the Villa and the nearest highway exit: Villa Giulio de la Ville: $950 \mathrm{~m}$; Villa Lucia: 1150 m; Villa Manes Rossi: 1.150 m; Villa Arena: 1060 m; Villa Durante: 1062 m.

- Villa Giulio de la Ville-PG: yes; PPK: free parking $150 \mathrm{~m}$ away; TF: The villa is on two levels; the main facade retains few elements of the original structure; on the entrance portal and on the windows are visible rests of the eighteenth-century decorations; AC, AD, PAFF, PDL, PPP: unknown; PST: yes;

- Villa Lucia-PG: yes; PPK: free parking 490 m away; TF: The building has two levels; the facade is linear and the windows have triangular tympanums; beyond the portal dominates an exedra courtyard; AC, AD, PAFF, PDL, PPP: unknown; PST yes;

- Villa Manes Rossi-PG: yes; PPK: free parking $450 \mathrm{~m}$ away; TF: The building is of clear neoclassical taste composed of unique floor; the facade has a piperno plinth and is decorated in Pompeian way; AC, AD, PAFF, PPP: unknown; PDL, PST: yes;

- Villa Arena-PG: yes; PPK: free parking $113 \mathrm{~m}$ away; TF: The facade is simple and with a piperno portal; at the first floor is decorated, the second one has a smooth surface with triangular and curved architraves; AC, AD, PPP: unknown; PAFF, PST, PDL: yes;

- Villa Durante-PG: yes; PPK: free parking 240 m away; TF: The continuous symmetrical curtain has an alternation of triangular and semicircular tympanums, respectively with shells and laurel leaves; in the center there is the Durante's family crest and a statue of St. Michael the Archangel; the villa has two portals with a smooth piperno frame that allow to access to two large atriums; AC: F. Sanfelice; AD, PAFF, PPP: unknown; PDL, PST: yes.

\section{$\underline{\text { CLE }}$}

- Type of property: All the buildings are private.

- Presence of a safeguard limitation derived from National Law: All the buildings are limited by the Decree of the Ministry of Cultural and Environmental Heritage of 19.10.1976. 


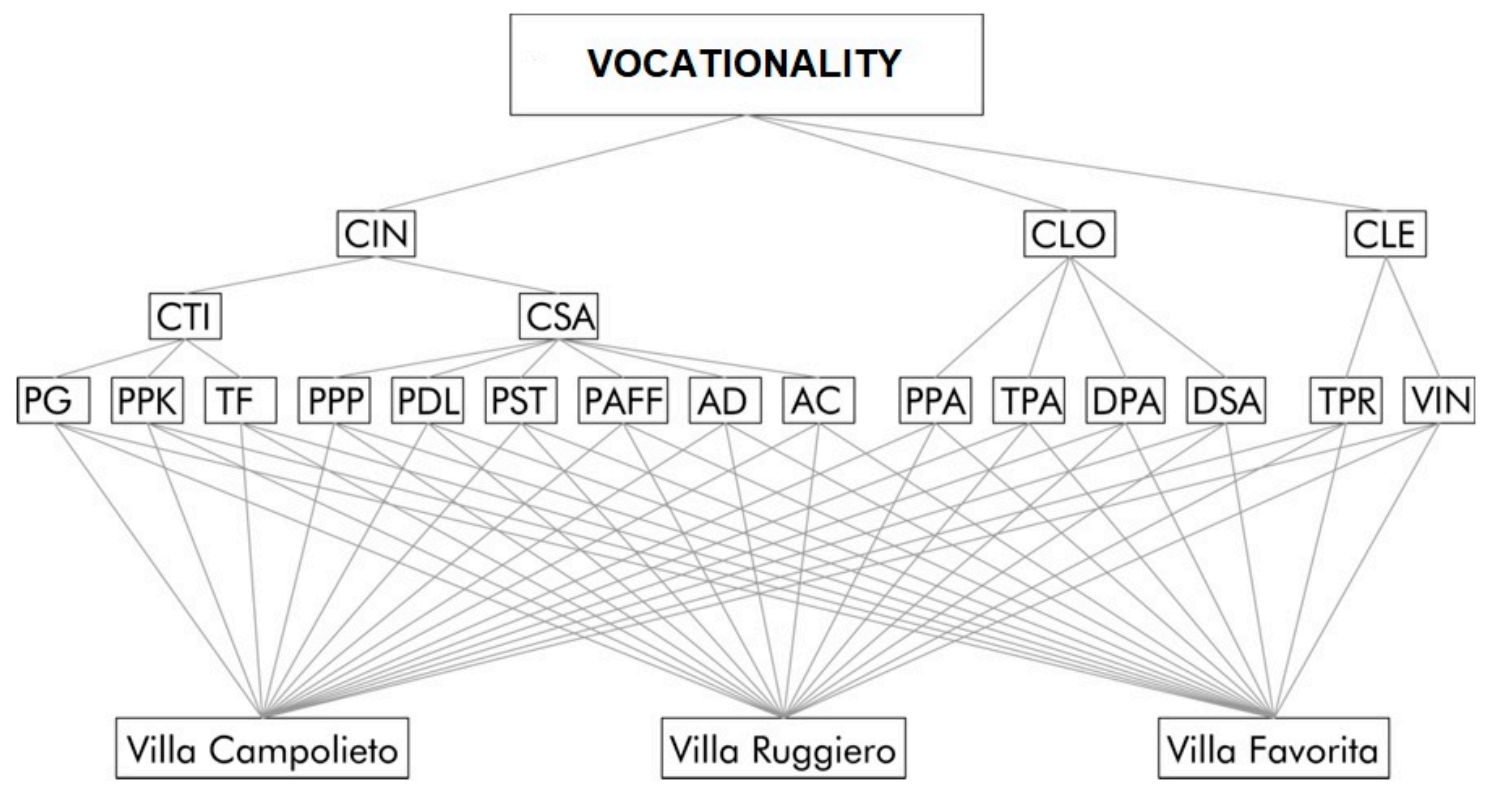

Figure 7. Model of assessment of the vocationality for the three villas managed by the Fondazione Ville Vesuviane, as a significant subset of the Vesuvian Villas system, and needed for the calibration of Model Ahp2.

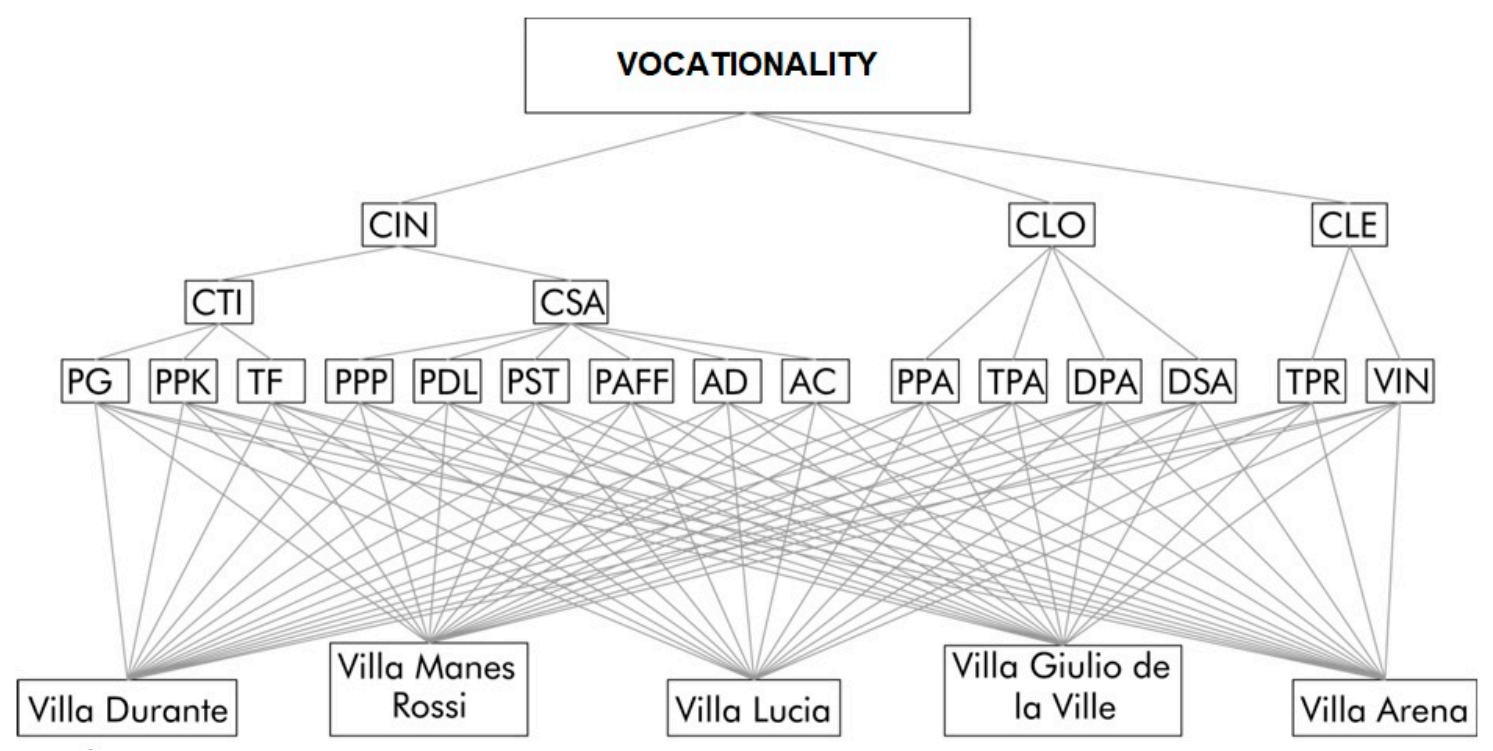

Figure 8. Model of assessment of the vocationality for the five villas of the case study (Ahp2).

\section{Model Calibration and Results}

The calibration of the model Ahp2 was carried out verifying the congruence of the ranking of the villas with known economic use (three villas managed by the Fondazione Ville Vesuviane: Villa Campolieto, Villa Ruggiero and Villa Favorita); more specifically, comparing the rankings obtained by models Ahp1 and Ahp2, or also comparing vector $u$ with vector $v$.

The results show that all the villas have a good level of economic vocation. The economic vocation model so validated is thus applied to the five villas of the case study. The results are in Figures 9 and 10. 


\begin{tabular}{|c|c|c|c|c|c|c|}
\hline 61 & ew synthesis fo & sions Main V & TroisiAHP & $1 \ldots$ & $\square$ & $x$ \\
\hline & $\begin{array}{l}\text { re are the } \\
\text { ernatives. } \\
\text { cisions M }\end{array}$ & $\begin{array}{l}\text { ynthesi } \\
\text { thesized } \\
\text { ow: Troi }\end{array}$ & $\begin{array}{l}\text { riorities } \\
\text { the ne } \\
1-\text { Fon }\end{array}$ & $\begin{array}{l}\text { for the } \\
\text { etwork S } \\
\text { idazione }\end{array}$ & $\begin{array}{l}\text { uper } \\
\text { sdmod }\end{array}$ & ^ \\
\hline & Name & Graphic & Ideals & Normals & Raw & \\
\hline VILLA & CAMPOLIETO & & 1.000000 & 0.653529 & 0.326765 & \\
\hline VILL & FAVORITA & & 0.081752 & 0.053428 & 0.026714 & \\
\hline VILL & RUGGIERO & & 0.448402 & 0.293043 & 0.146522 & \\
\hline Okay & Copy Values & & & & & $v$ \\
\hline
\end{tabular}

Figure 9. Calibration phase: Overall synthesized priorities for the alternatives (Model Ahp1).

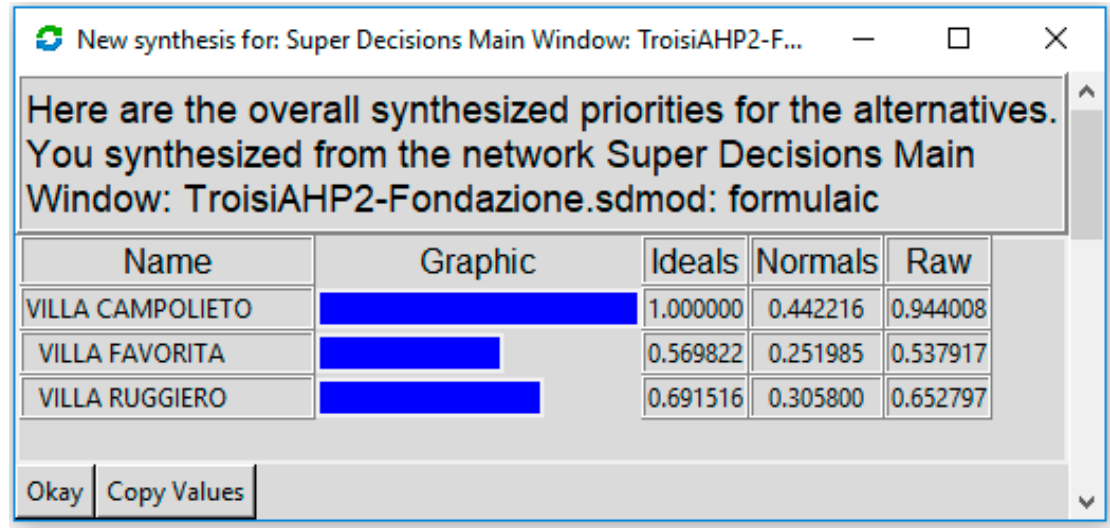

Figure 10. Calibration phase: Overall synthesized priorities for the alternatives (Model Ahp2).

It is clear that the best potentials are those of Villa Durante with the value 0.866 (see Figure 11), and then Villa Giulio de la Ville (0.779), Villa Arena (0.721), Villa Lucia (0.660) and Villa Manes Rossi (0.650).

However, when trying to evaluate individual clusters of indicators, the final situation is different.

\begin{tabular}{|c|c|c|c|c|c|}
\hline \multicolumn{6}{|c|}{ New synthesis for: Super Decisions Main Window: TroisiAHP2-... } \\
\hline \multicolumn{6}{|c|}{$\begin{array}{l}\text { Here are the overall synthesized priorities for the alternatives. } \\
\text { You synthesized from the network Super Decisions Main } \\
\text { Window: TroisiAHP2-Modello.sdmod: formulaic }\end{array}$} \\
\hline Name & Graphic & Ideals & Normals & Raw & \\
\hline VILLA ARENA & & 0.833015 & 0.196183 & 0.721959 & \\
\hline VILLA DURANTE & & 1.000000 & 0.235510 & 0.866682 & \\
\hline VILLA GIULIO DE LA VILLE & & 0.899970 & 0.211952 & 0.779987 & \\
\hline VILLA LUCIA & & 0.762663 & 0.179615 & 0.660986 & \\
\hline VILLA MANES ROSSI & & 0.750458 & 0.176740 & 0.650408 & \\
\hline Okay Copy Values & & & & & $\checkmark$ \\
\hline
\end{tabular}

Figure 11. Results: Overall synthesized priorities for the alternatives (Model Ahp2).

Analyzing only the characteristics about the villa's localization (CLO) the results are shown in Figure 12. 
The highest value is still that of Villa Durante, but the other values are changed, and also the order of the villas.

\begin{tabular}{|c|c|c|c|c|c|c|}
\hline$\approx N$ & ew synthesis for: Sul & ler CLO & & - & $\square$ & \\
\hline & $\begin{array}{l}\text { Here are the } \\
\text { alternatives. } \\
\text { Subnet unde }\end{array}$ & $\begin{array}{l}\text { all synthe } \\
\text { synthesi }\end{array}$ & $\begin{array}{l}\text { priorit } \\
\text { om the }\end{array}$ & $\begin{array}{l}\text { ies for th } \\
\text { networ }\end{array}$ & & A \\
\hline & Name & Graphic & Ideals & Normals & Raw & \\
\hline VILL & A ARENA & & 0.915838 & 0.275860 & 0.137930 & \\
\hline VILL & DURANTE & & 1.000000 & 0.301210 & 0.150605 & \\
\hline VILLA & GIULIO DE LA VILLE & & 0.828756 & 0.249630 & 0.124815 & \\
\hline & A LUCIA & & 0.278505 & 0.083889 & 0.041944 & \\
\hline VILLA & MANES ROSSI & & 0.296841 & \begin{tabular}{|l|l|}
0.089412 \\
\end{tabular} & 0.044706 & \\
\hline Okay & Copy Values & & & & & 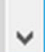 \\
\hline
\end{tabular}

Figure 12. Overall synthesized priorities for the alternatives from the network characteristics about the villa's localization (CLO) (Model Ahp2).

We continue the verification with the other two categories of indicators, CLE (characteristics about the ownership and legal structure, see Figure 13) and CIN (intrinsic characteristics of the villa, see Figure 14), and the results change each time.

\begin{tabular}{|c|c|c|c|c|c|c|}
\hline$\Rightarrow \mathrm{N}$ & ew synthesis for: Sub & er CLE & & - & $\square$ & K \\
\hline & $\begin{array}{l}\text { Here are the } \\
\text { alternatives. } \\
\text { Subnet unde }\end{array}$ & $\begin{array}{l}\text { all synth } \\
\text { synthes }\end{array}$ & $\begin{array}{l}\text { priorit } \\
\text { om the }\end{array}$ & $\begin{array}{l}\text { ties for th } \\
\text { network }\end{array}$ & & $\wedge$ \\
\hline & Name & Graphic & Ideals & Normals & Raw & \\
\hline VILI & A ARENA & & 0.790717 & \begin{tabular}{||l|}
0.181441 \\
\end{tabular} & 0.090720 & \\
\hline VILL & DURANTE & & 0.775421 & \begin{tabular}{||l|l|}
0.177931 \\
\end{tabular} & 0.088965 & \\
\hline VILLA & GIULIO DE LA VILLE & & 1.000000 & 0.229464 & 0.114732 & \\
\hline & A LUCIA & & 0.895926 & 0.205582 & 0.102791 & \\
\hline VILLA & MANES ROSSI & & 0.895926 & 0.205582 & 0.102791 & \\
\hline Okay & Copy Values & & & & & $\checkmark$ \\
\hline
\end{tabular}

Figure 13. Overall synthesized priorities for the alternatives from the network CLE (Model Ahp2).

The valuations highlight the more relevant indicators for the definition of the vocationality of the properties object to study: The aesthetic value, the presence of external areas and the more or less fractioned ownership regime undoubtedly have a very important weight. 


\begin{tabular}{|c|c|c|c|c|c|c|}
\hline 51 & ew synthesis for: Sul & $\operatorname{der} \mathrm{CIN}$ & & - & $\square$ & \\
\hline & $\begin{array}{l}\text { Here are the } \\
\text { alternatives. } \\
\text { Subnet unde }\end{array}$ & $\begin{array}{l}\text { all synthe } \\
\text { synthesiz }\end{array}$ & $\begin{array}{l}\text { d priorit } \\
\text { rom the }\end{array}$ & $\begin{array}{l}\text { ties for th } \\
\text { network }\end{array}$ & & 1 \\
\hline & Name & Graphic & Ideals & Normals & Raw & \\
\hline VIL & A ARENA & & 0.436105 & 0.190227 & 0.095113 & \\
\hline VILL & A DURANTE & & 1.000000 & 0.436194 & 0.218097 & \\
\hline VILLA & GIULIO DE LA VILLE & & 0.225393 & 0.098315 & 0.049158 & \\
\hline & LA LUCIA & & 0.342519 & 0.149405 & 0.074702 & \\
\hline VILL & MANES ROSSI & & 0.288540 & 0.125859 & 0.062930 & \\
\hline Okay & Copy Values & & & & & $\checkmark$ \\
\hline
\end{tabular}

Figure 14. Overall synthesized priorities for the alternatives from the network intrinsic characteristics of the villa (CIN) (Model Ahp2).

Finally, it is possible to evaluate how strong an alternative choice for the calculation of vocationality is through a sensitivity analysis (see Figures 15-17).

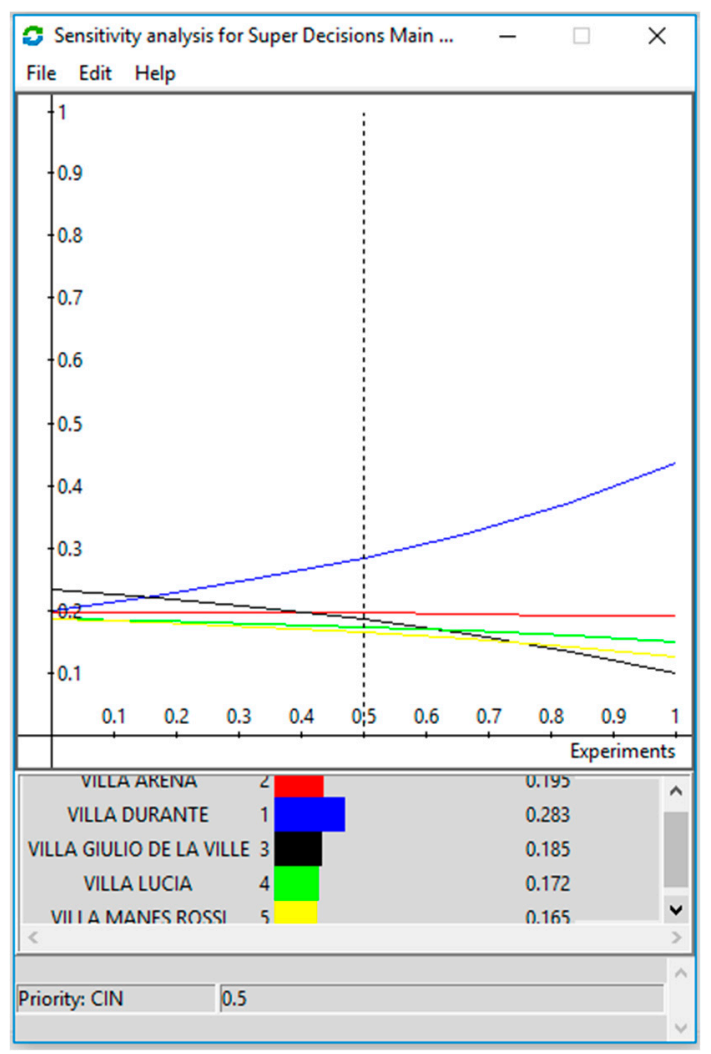

Figure 15. Sensitivity analysis based on the CIN criteria (intrinsic characteristics).

The diagram with colored bars in the table shows how the results of vocationality change when trying to modify the values of the CIN by $50 \%$ (see Figure 15). Following are similar examples but with variation in CLO (see Figure 16) and CLE criteria (see Figure 17). 


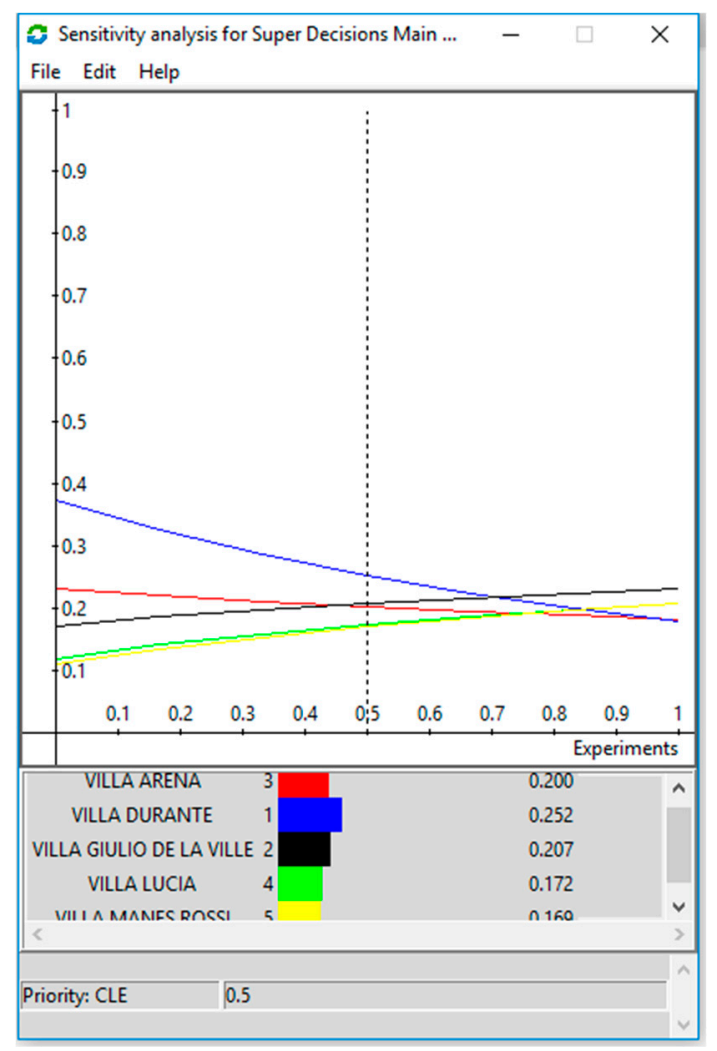

Figure 16. Sensitivity analysis based on the CLE criteria (characteristics about the ownership and legal structure).

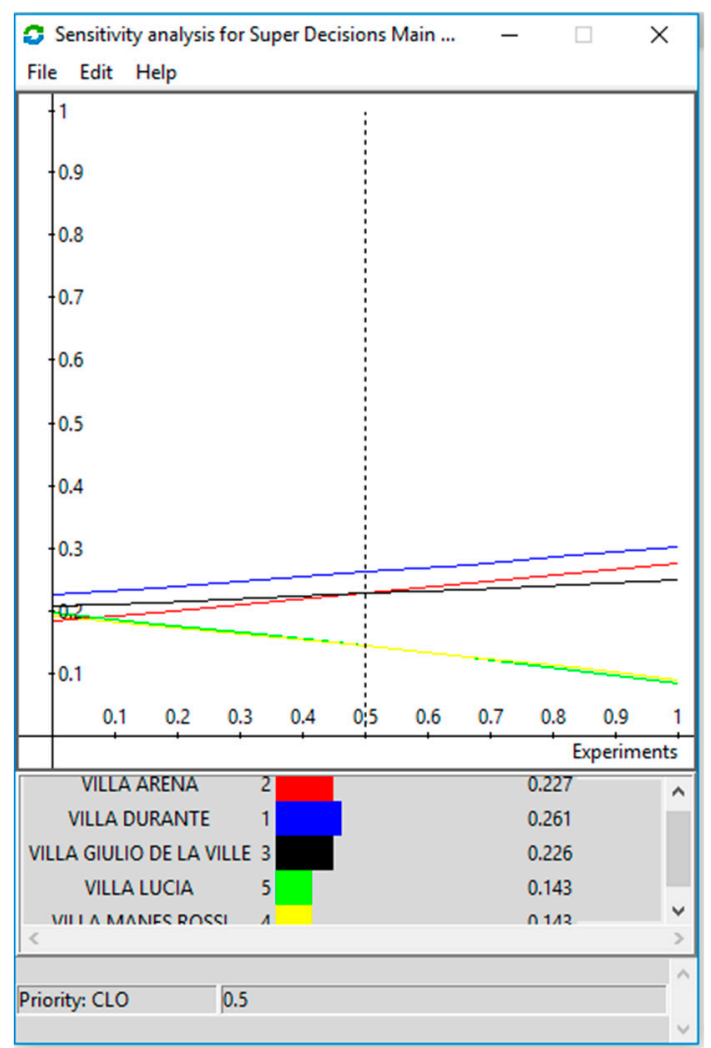

Figure 17. Sensitivity analysis based on the CLO criteria (characteristics of localization). 


\section{Conclusions}

The Vesuvian Villas, although a few are different from a functional and structural point of view, have unfortunately undergone several changes over time. Many of these villas are still used as homes today, but the original functional relationship between agricultural production and country residence has gone down (see Figure 18). This is due, in particular, to the poor profitability of the buildings and the division of properties, which, over time, have caused the alienation of soils and the worsening of environmental conditions. No villa performs the function for which it was built; most of them are used as a rustic house, warehouse, restaurant or, at best, in a converted house or museum.

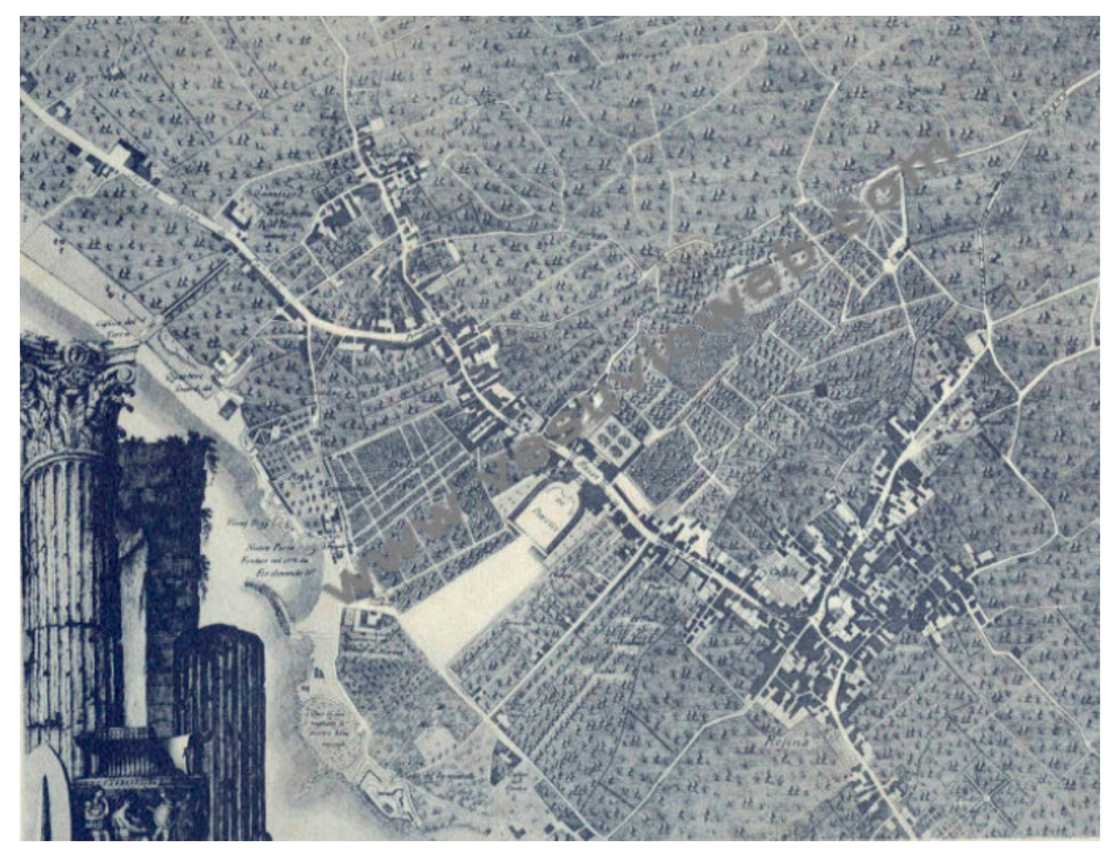

Figure 18. G. Carafa, Duke of Noja. Ancient topographic map of Naples and its hinterlands (1775), particularly of the "Strada Regia delle Calabrie".

In any case, they remain identity assets that connote geographic spaces and represent an inalienable patrimony of historical, environmental and artistic values to be protected and enhanced, since they nourish the identity of a community and guarantee a historical and cultural continuity.

The study proposes a model of analysis and evaluation of the vocationality of historical-architectural buildings in order to assess economic uses compatible with the needs of protection and conservation. Despite the evidence of these potentialities, the difficulties to convert qualitative variables into quantitative algorithms are a complex issue. These difficulties were particularly evident in the construction of the hierarchical model for the evaluation of vocationality. A further objective difficulty is the substantial absence of consolidated models of conservative economic re-use to be considered for the calibration of the potential vocationality. Not to underestimate, then, the usual and chronic lack of economic information: On the one hand, there are widely available information about historical and architectural aspects of the buildings, as well as their state of maintenance; on the other hand, there is total lack of information on the forms of buildings management and their consequent economic results [18-20]. This gap is only partially filled through the use of indirect indicators, such as revenue, grade and type of use. Only recently, due to high maintenance costs, the owners of the Vesuvian Villas have begun to consider economic use as a possible alternative to abandonment and, in this sense, the initiatives remain rather limited and still in the start-up phase. Therefore, the analysis carried out is a first attempt at reading a particularly changeable and unstable reality, where the use of the architectural artefact appears to be poised between distortive transformations (such as the intensive residential destination in peripheral urban areas) and recovery to original function as prestigious 
residence converted for public uses (libraries, corporate offices, museums, etc.). The applied model has demonstrated a good ability to identify the most favored realities to accommodate the forms of use compatible with conservation, also thanks to the possibility offered by the hierarchical analysis to build very articulated models, and being able to capture and incorporate into the evaluation more different aspects. Further model developments may be based on an improvement in the quality and quantity of economic data, in order to improve the fitting of the model. Evaluating the vocationality in relation to different forms of economic use can therefore provide useful indications to operate stratifications on the heritage of the Vesuvian Villas, in order to suggest private management strategies for individual assets; support the formation of adequate protection policies; and, last but not least, improve the efficiency of the few public funds available for the protection of a heritage unique for consistency and historical-architectural relevance.

Author Contributions: The paper is attributed in equal part to all authors. All authors have read and agreed to the published version of the manuscript.

Funding: This research received no external funding.

Conflicts of Interest: The authors declare no conflict of interest.

\section{References}

1. CHCfE, Cultural Heritage Counts for Europe, CHCfE Consortioum, 2015. Available online: https://www. ehhfeu/ (accessed on 20 December 2019).

2. Council of the European Union. Conclusions on cultural heritage as a strategic resource for a sustainable Europe. In Proceedings of the Education, Youth, Culture and Sport Council Meeting, Brussels, Belgium, 20 May 2014.

3. European Commission. Towards an integrated approach to cultural heritage for Europe COM(2014) 477 final. In Proceedings of the Committee on Culture and Education, Brussels, Belgium, 22 July 2014.

4. Forte, F.; Listokin, D. Evaluating Impacts of Cultural Heritage Valorization - or Historic Preservation-: A Comparative Overview Italy - USA. In Proceedings of the XIV International Forum, Le vie dei Mercanti, La Scuola di Pitagora, Napoli, Italy, June 2016.

5. ISTAT, Rapporto BES 2018. Il benessere equo e sostenibile in Italia, Istat, Rome, 2018. Available online: https://www.istat.it/it/archivio/224669 (accessed on 22 January 2020).

6. Greffe, X. The economic Value of Heritage. Colloquio di Ahmedabad, National Trust of India. 1998. Available online: http://www.planningstudies.org/pdf/Raphael\%20Greffe-\%20E\%20(formatted).pdf (accessed on 22 January 2020).

7. Di Stefano, R. Il recupero dei valori; Edizioni Scientifiche Italiane: Napoli, Italy, 1979.

8. Forte, F. Historic, Artistic and Cultural Patrimony for a "Habitable City": Incentives for Care. In Green Energy and Technology; Springer: Heidelberg, Germany, 2018; pp. 233-243.

9. Papa, A. Valorizzazione e gestione del patrimonio culturale nel Codice dei beni culturali e del paesaggio. In BILANCIA, Paola Ed. La valorizzazione dei beni culturali. Modelli giuridici e di gestione integrata. Milano, Franco Angeli. 2006. Available online: https://www.francoangeli.it/Ricerca/scheda_libro.aspx?Id=14504 (accessed on 22 January 2020).

10. Forte, C. Valore di scambio e valore d'uso sociale dei beni culturali immobiliari; Editrice Arte Tipografica: Napoli, Italy, 1977.

11. Council of Europe. The private management of cultural property, Parliamentary Assembly Recommendation 1730 (2005). Available online: https://assembly.coe.int/nw/xml/XRef/Xref-XML2HTML-EN.asp?fileid= 17394\&lang=en (accessed on 22 January 2020).

12. Forte, F.; Formisano, R. Additional services in the management of Cultural Heritage: the paradox of archeological site of Pompei. In Proceedings of the XIII International Forum, Le vie dei Mercanti, La Scuola di Pitagora, Napoli, Italy, 11-13 June 2015.

13. Forte, F.; Rupe, M. Sponsorship in the enhancement of Cultural Heritage and the role of Creative Industry: some evaluative aspects. In Proceedings of the XIII International Forum, Le vie dei Mercanti, La Scuola di Pitagora, Napoli, Italy, 11-13 June 2015. 
14. Listokin, D. Landmarks Preservation \& the Property Tax: Assessing Landmark Buildings for Real Taxation Purposes; Routledge: London, UK, 2012.

15. Monti, L. Il patrimonio storico e artistico private nel contesto dell'economia della cultura: una concreta opportunità di sviluppo. Intervention at the XXXVIII Members'Assembly of A.D.S.I. meeting Beni culturali: oneri o risorse? In Proceedings of the L'impatto economico del patrimonio storico-architettonico sull'economia del paese, Rome, Italy, 13 May 2015.

16. D'Alpaos, C.; Rosato, P.; Zanatta, V. Il riuso economico degli edifici storici: un modello di valutazione gerarchica. In Riconversione di Manufatti Storici in Musei, I musei di oggi negli edifici di ieri, Proceedings of the Atti delle giornate di studio, Torino, Genova, Italy, 7-8 May 2001; Ientile, R., Ed.; Name: Genova, Italy, 2002.

17. Saaty, T.L.; De Paola, P. Rethinking Design and Urban Planning for the Cities of the Future. Buildings 2017, 7, 76. [CrossRef]

18. Della Spina, L.; Calabrò, F. Decision Support Model for Conservation, Reuse and Valorization of the Historic Cultural Heritage. In Computational Science and Its Applications-ICCSA 2018, Proceedings of the ICCSA 2018. Lecture Notes in Computer Science, Melbourne, Australia, July 2018; Gervasi, O., Ed.; Springer: Cham, Switzerland, 2018; Volume 10962. [CrossRef]

19. Della Spina, L. Scenarios for a Sustainable Valorisation of Cultural Landscape as Driver of Local Development. In New Metropolitan Perspectives. ISHT 2018. Smart Innovation, Systems and Technologies; Calabrò, F., Della Spina, L., Bevilacqua, C., Eds.; Springer: Cham, Switzerland, 2018; Volume 100. [CrossRef]

20. Della Spina, L. Historical Cultural Heritage: Decision Making Process and Reuse Scenarios for the Enhancement of Historic Buildings. In New Metropolitan Perspectives. ISHT 2018. Smart Innovation, Systems and Technologies; Calabrò, F., Della Spina, L., Bevilacqua, C., Eds.; Springer: Cham, Switzerland, 2018; Volume 101. [CrossRef]

(C) 2020 by the authors. Licensee MDPI, Basel, Switzerland. This article is an open access article distributed under the terms and conditions of the Creative Commons Attribution (CC BY) license (http://creativecommons.org/licenses/by/4.0/). 